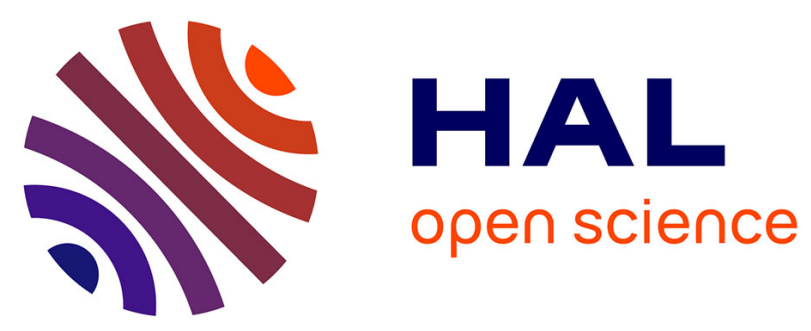

\title{
Assimilation of TES CO into a global CTM: first results
}

N. A. D. Richards, Q. Li, K. W. Bowman, J. R. Worden, S. S. Kulawik, G. B.

Osterman, H. M. Worden, J.-F. Lamarque, B. V. Khattatov

\section{To cite this version:}

N. A. D. Richards, Q. Li, K. W. Bowman, J. R. Worden, S. S. Kulawik, et al.. Assimilation of TES CO into a global CTM: first results. Atmospheric Chemistry and Physics Discussions, 2006, 6 (6), pp.11727-11743. hal-00302291

\section{HAL Id: hal-00302291 \\ https://hal.science/hal-00302291}

Submitted on 22 Nov 2006

HAL is a multi-disciplinary open access archive for the deposit and dissemination of scientific research documents, whether they are published or not. The documents may come from teaching and research institutions in France or abroad, or from public or private research centers.
L'archive ouverte pluridisciplinaire HAL, est destinée au dépôt et à la diffusion de documents scientifiques de niveau recherche, publiés ou non, émanant des établissements d'enseignement et de recherche français ou étrangers, des laboratoires publics ou privés. 
Atmos. Chem. Phys. Discuss., 6, 11727-11743, 2006

www.atmos-chem-phys-discuss.net/6/11727/2006/

(C) Author(s) 2006. This work is licensed

under a Creative Commons License.

Assimilation of TES

CO

N. A. D. Richards et al.

\section{Assimilation of TES CO into a global CTM: first results}

N. A. D. Richards ${ }^{1}$, Q. Li ${ }^{1}$, K. W. Bowman ${ }^{1}$, J. R. Worden ${ }^{1}$, S. S. Kulawik ${ }^{1}$, G. B. Osterman ${ }^{1}$, H. M. Worden ${ }^{1}$, J.-F. Lamarque ${ }^{2}$, and B. V. Khattatov ${ }^{3}$

${ }^{1}$ Jet Propulsion Laboratory, California Institute of Technology, Pasadena, CA, USA

${ }^{2}$ National Center for Atmospheric Research, Boulder, CO, USA

${ }^{3}$ Fusion Numerics, Boulder, CO, USA

Received: 18 October 2006 - Accepted: 14 November 2006 - Published: 22 November 2006

Correspondence to: N. A. D. Richards (nigel.richards@jpl.nasa.gov)

Title Page

Abstract

Introduction

Conclusions

References

Tables

Figures

14

I

4

Back

$>$

Close

Full Screen / Esc

Printer-friendly Version

Interactive Discussion 


\section{Abstract}

We present results from the first assimilation of carbon monoxide (CO) observations from the Tropospheric Emission Spectrometer (TES) into a global three-dimensional (3-D) chemistry and transport model (CTM). A sequential sub-optimal Kalman filter 5 assimilation scheme (Khattatov et al., 2000) was applied to assimilate TES CO profiles during November 2004 into the GEOS-Chem global 3-D CTM. The assimilation results were compared with MOPITT and MOZAIC observations. The assimilation significantly improves model simulation of $\mathrm{CO}$ in the middle to upper troposphere, where the MOPITT versus model bias was reduced by up to two-thirds. Assimilation results show higher levels of $\mathrm{CO}$ in the southern tropics, consistent with MOPITT observations. We find good agreement between the TES assimilated model estimates of CO and in situ measurements from the MOZAIC program, which shows a negative bias of up to $10 \mathrm{ppbv}$ in middle and upper tropospheric TES CO. The results demonstrate how assimilation can be used for non-coincident validation of TES CO profile retrievals.

\section{Introduction}

Carbon monoxide (CO) is an excellent tracer for pollution transport (Liu et al., 2003). Global coverage provided by space-based remote sensing of $\mathrm{CO}$, such as from the Measurements Of Pollution In The Troposphere (MOPITT) (Drummond et al., 1992) and Atmospheric Infrared Sounder (AIRS) (McMillan et al., 2005) satellite instruments, has been used to track inter-continental transport of pollution (e.g., Heald et al., 2003). Launched in July 2004, the Tropospheric Emission Spectrometer (TES) onboard the Aura satellite provides global 3-D mapping of both $\mathrm{CO}$ and ozone among other trace gases (Beer et al., 2001). Validation of the TES CO product is critical to understanding its value for further scientific analyses. We demonstrate here a useful method for conducting validation analyses using non-coincident measurements. We present initial intercomparisons of the retrieved TES CO columns with MOPITT observations

Assimilation of TES co

N. A. D. Richards et al.

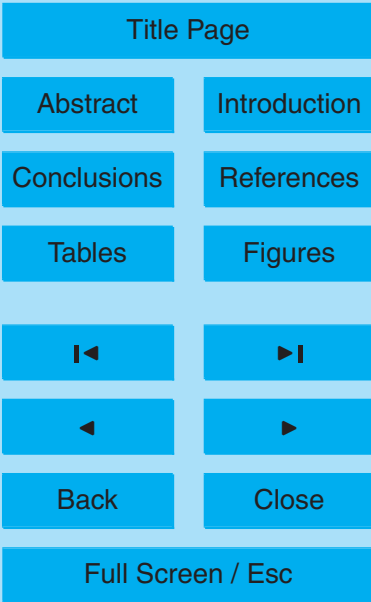

Printer-friendly Version

Interactive Discussion 
and mixing ratio profiles with MOZAIC observations (Marenco et al., 1998; Nédélec et al., 2003, 2005). MOPITT CO retrievals of mixing ratios and column amounts have been extensively validated using coincident in situ aircraft observations (Emmons et al., 2004).

5 Chemical data assimilation is a valuable tool for the validation of non-coincident observations (e.g., Levelt et al., 1998). Space-time data assimilation techniques provide the necessary framework to combine different sources of information into a single product in an optimal manner, taking into account the uncertainties of each component (Errico, 1999). Khattatov et al. (2000) presented a sequential assimilation approach

10 to combine UARS MLS stratospheric ozone with results from a global 3-D CTM. The assimilation technique consisted of a sub-optimal Kalman filter with explicit calculation of the evolution of the model error variance. This technique has since been used in the assimilation of trace gases (e.g., Lamarque et al., 2004; Yudin et al., 2004) and aerosols (e.g., Yu et al., 2003). This sub-optimal Kalman filter is applied in the present 15 study to assimilate TES CO mixing ratio profiles during 1-15 November 2004 into the GEOS-Chem model (Bey et al., 2001a).

\section{TES CO observations}

TES is an infrared Fourier transform spectrometer that measures atmospheric thermal emission over the spectral range $650-2250 \mathrm{~cm}^{-1}$, with a nadir footprint of $5.3 \mathrm{~km}$ across track and $8.5 \mathrm{~km}$ along track for the 16-detector average (Beer et al., 2001). It was designed to provide simultaneous vertical information on tropospheric ozone, CO and other trace gases on a global basis. TES has two basic science operating modes: Global Survey and Special Observations. Global Surveys are conducted every other day while special observations are taken as needed in between Global Surveys. For

the Global Survey data used in this analysis, the nadir observations have a spacing of about $5^{\circ}$ along the orbit track. Global Surveys taken after 21 May 2005 have increased nadir sampling, $\sim 1.6^{\circ}$ spacing along the orbit track, but no longer include routine limb

\section{ACPD}

$6,11727-11743,2006$

Assimilation of TES CO

N. A. D. Richards et al.

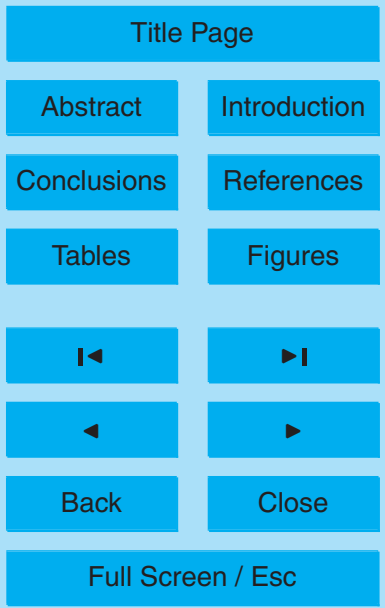

Printer-friendly Version

Interactive Discussion 
observations. The assimilation described here also ingests data from TES Step \& Stare special observations which consists of a series of nadir measurements taken at a spacing of $35 \mathrm{~km}$ along the Aura orbit track. An overview of the TES retrieval algorithm and predicted errors are discussed in Bowman et al. (2002) and Worden et 5 al. (2004). Recent observations with the TES nadir CO measurements are described by Rinsland et al. (2005).

During 1-15 November 2004 there were six TES Global Surveys and 10 Step \& Stares special observations. This represents one global coverage cycle for TES and is the first available continuous set of TES observations. Release V001 TES data are 10 used in this study. TES CO profiles were assimilated into GEOS-Chem once every hour, same as the model chemistry time step. TES CO profiles, averaging kernels, error covariances, and a priori profiles were mapped down from the original 88 pressure levels to a reduced 14-level pressure grid for computational considerations. The mapping was linear with respect to the logarithm of pressure and the mixing ratio of $\mathrm{CO}$.

15 This mapping does not significantly affect the assimilation because typical CO profiles can be well represented by this reduced grid. The TES data were filtered according to the quality flags provided (Osterman et al., 2005). Retrievals with surface pressure less than $825 \mathrm{hPa}$ were removed to avoid complications associated with variable topography. Additionally, data were excluded for latitudes higher than 60 degrees, where there is little thermal contrast and therefore significantly reduced vertical information.

\section{Model description}

GEOS-Chem is driven by assimilated meteorological observations from the Goddard Earth Observing System (GEOS) of the NASA Global Modeling and Assimilation Office (GMAO). We use here GEOS-Chem version 7.1.1 (http://www-as.harvard.edu/ chemistry/trop/geos/). The simulation of transport in the GEOS-Chem model uses archived GEOS-4 data for winds, mixing depths, and convective mass fluxes. In this study, GEOS-4 data for 2004 are used with a horizontal resolution of $4^{\circ} \times 5^{\circ}$ and 30

Assimilation of TES CO

N. A. D. Richards et al.

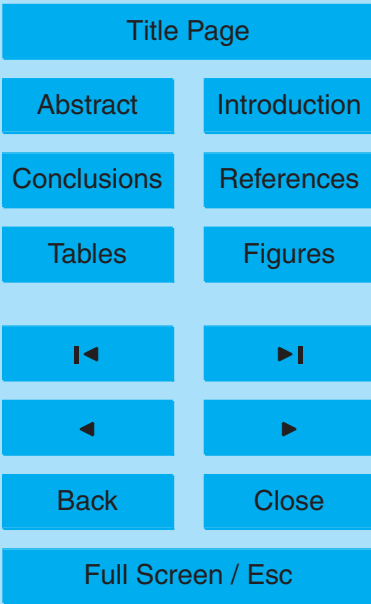

Printer-friendly Version

Interactive Discussion 
sigma-pressure hybrid levels in the vertical. CO-only simulations are conducted using archived $\mathrm{OH}$ fields from a full chemistry simulation (Bey et al., 2001b). Global emissions of $\mathrm{CO}$ are described in Bey et al. (2001a) with updates, with biomass burning emissions described by Duncan et al. (2003) and biofuel emissions by Yevich and Lo5 gan (2003). GEOS-Chem simulation and assimilation of CO were conducted for 1-15 November 2004 with a two-month spin-up. We focus our analysis on 15 November.

\section{Assimilation Approach}

The assimilation scheme employed here is a sub-optimal Kalman filter scheme following Khattatov et al. (2000). A brief description of the assimilation method is given 10 here. At each assimilation time step ( $\mathrm{t}$ ) the state vector $\boldsymbol{x}_{t}^{a}$, whose elements contain the estimated global $\mathrm{CO}$ concentrations, also called the analysis, is given by:

$\boldsymbol{x}_{t}^{a}=\boldsymbol{x}_{t}+\mathbf{K}\left(\mathbf{y}-\mathbf{H} \mathbf{x}_{t}\right)$

where $\boldsymbol{x}_{t}$ consists of the model CO field at time $t, \mathbf{y}$ contains the observed CO concentrations and $\mathbf{K}$ is the Kalman Gain matrix and is given by:

where $\mathbf{B}_{t}$ is the model (also known as forecast or background) error covariance at time t, $\mathbf{O}$ is the error covariance matrix of the observations and $\mathbf{R}$ is the representativeness error covariance. $\mathbf{H}$ is known as the observation operator and represents both the horizontal mapping of model $\mathrm{CO}$ profiles to the observation location and the vertical smoothing of model profiles to the resolution of the observations. The horizontal mapping is performed using 2-dimensional linear interpolation. In this study, vertical smoothing and accounting for the TES a priori constraint vector $\boldsymbol{x}_{a}$ are achieved by applying the TES averaging kernel, A, to GEOS-Chem CO profile $\boldsymbol{x}_{m}$ through the following linear transformation (Rodgers, 2000)

Assimilation of TES CO

N. A. D. Richards et al.

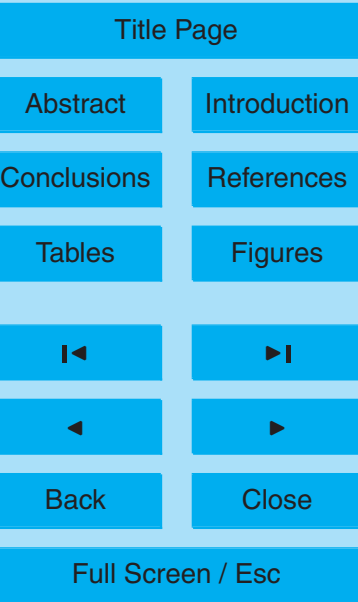

Printer-friendly Version

Interactive Discussion 
Consequently, this transformation accounts for both the bias and smoothing in the TES retrievals (Jones et al., 2003). TES a priori constraints for $\mathrm{CO}$ are obtained from a climatology derived from the MOZART (Brasseur et al., 1998; Park et al., 2004) model results. The logarithm of TES $\mathrm{CO}$ mixing ratio profiles and GEOS-Chem CO fields

5 are used in Eqs. (1) and (3) since the TES averaging kernels relate to changes in the logarithm of $\mathrm{CO}$ mixing ratios.

After each assimilation step, $\boldsymbol{x}_{t}^{a}$ is used as the initial condition for GEOS-Chem to predict CO concentrations for the next model time step. For this study, the initial GEOSChem model error variance was set to $20 \%$. The time evolution of the GEOS-Chem 10 model error covariance was modeled by treating the diagonals as a passive tracer in the model, with the off-diagonal elements parameterized according to Khattatov et al. (2000). Horizontal and vertical correlation lengths of $125 \mathrm{~km}$ and $0.7 \mathrm{~km}$, respectively, and an error growth term of $18 \% /$ day are used in the model error covariance parameterization. These parameters are consistent with those used by Lamarque et 15 al. (2004) in the assimilation of MOPITT CO into the MOZART model, who found that small variations in these parameters do not significantly affect the results of the assimilation.

\section{Results and discussion}

Figure 1 shows GEOS-Chem simulated CO concentrations with and without assimi20 lating TES data and the difference between the two at $5.5 \mathrm{~km}$ on 15 November 2004, the last day of the assimilation. The assimilated and non-assimilated (i.e., free-running simulation) fields exhibit many of the same large scale features such as the higher CO concentrations in the northern hemisphere due to anthropogenic emissions and high CO concentrations over Africa and South America due to biomass burning emissions.

25 However, the assimilated field shows much higher $\mathrm{CO}$ concentrations than the nonassimilated field, particularly in the southern tropics where differences of up to $50 \mathrm{ppbv}$ at $500 \mathrm{mb}$ are evident. It is known that there is widespread biomass burning throughout

Assimilation of TES CO

N. A. D. Richards et al.

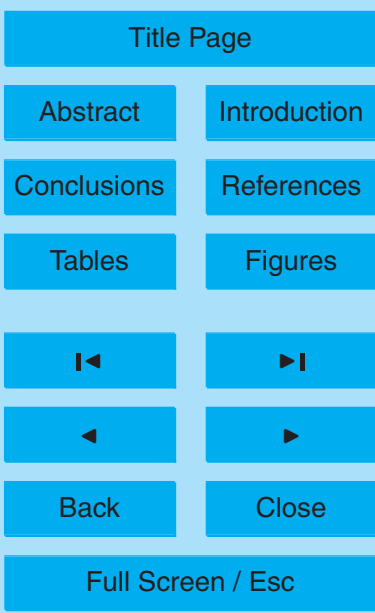

Printer-friendly Version

Interactive Discussion 
much of the tropics during Austral spring (Duncan et al., 2003). The abovementioned differences are likely due to underestimated biomass burning emissions in Southern Africa and South America as prescribed in the model, consistent with previous inverse studies using MOPITT data (Arellano et al., 2004). The simulations presented here use

5 climatological biomass burning emission inventories that are not year-specific, thus, the time, location and amount of $\mathrm{CO}$ released will not represent the actual emissions. A comparison was also conducted against a GEOS-Chem simulation using year-specific biomass burning emissions for 2004 from the GFED 2.0 inventory (van der Werf et al., 2006). We found that the southern tropical biomass burning emissions of $C O$ in GFED 102.0 are $40-90 \%$ lower than those in Duncan et al. (2003), resulting in even larger differences. Another possible reason for the model underestimation of $\mathrm{CO}$ concentrations in biomass burning regions could be related to the injection height of the emissions - in our simulation, biomass burning $\mathrm{CO}$ is emitted into the boundary layer. A recent study by Turquety et al. (2006) ${ }^{1}$ has shown that by releasing a significant fraction of the 15 biomass burning emissions into the upper troposphere, GEOS-Chem is able to better reproduce MOPITT CO observations downwind from the source regions.

The observation minus forecast (OMF) provides a test of the quality of the assimilation and also highlights systematic differences between the assimilated product and the data. A time series of OMF during the assimilation period is shown in Fig. 1 for three tropical ocean regions. The OMFs for all three regions decrease with time, indicating that the assimilation system is performing well and incorporating information from the TES observations. Although these differences decrease over time as TES data are assimilated into the model, the OMF will not reach zero since not only do we not have perfect observations there is also an underestimation of biomass burning emissions in the model that is not corrected by the assimilation.

${ }^{1}$ Turquety, S., Logan, J. A., Jacob, D. J., et al.: Inventory of boreal fire emissions for North America in 2004: the importance of peat burning and pyro-convective injection, J. Geophys. Res., submitted, 2006.

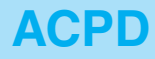

6, 11727-11743, 2006

Assimilation of TES CO

N. A. D. Richards et al.

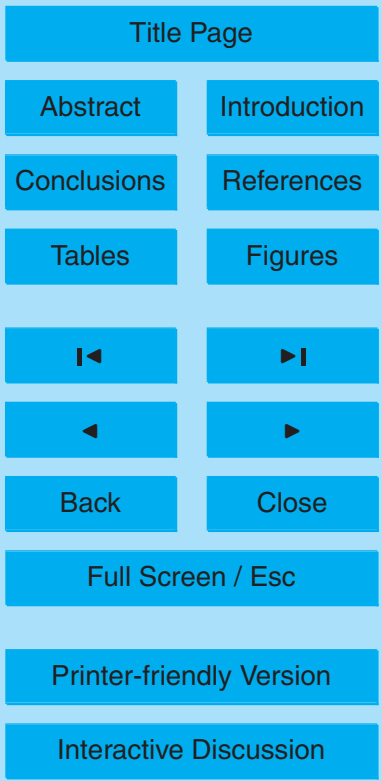

EGU 


\subsection{Comparison with MOPITT}

MOPITT data for 15 November 2005 were compared to the assimilated and nonassimilated GEOS-Chem results. For the comparison assimilated and non-assimilated GEOS-Chem profiles were extracted at the time and location of each MOPITT obser-

5 vation. The MOPITT averaging kernels were then applied to account for the vertical smoothing and a priori influence inherent in the retrieved MOPITT profiles (Deeter et al., 2004). The MOPITT and transformed GEOS-Chem profiles were then binned onto the GEOS-Chem $4^{\circ} \times 5^{\circ}$ grid.

Emmons et al. (2004) have shown that the MOPITT Phase $2 \mathrm{CO}$ mixing ratio pro10 files used here exhibit, on average, a positive bias of $1 \%$ in the upper troposphere with larger biases observed in specific cases. We find that the assimilation of TES data into GEOS-Chem significantly reduces the model - MOPITT bias throughout the tropospheric profile by up to two-thirds (Table 1), particularly in the middle to upper troposphere. Figure 2 shows a scatter-plot of GEOS-Chem and MOPITT CO con15 centrations at $500 \mathrm{hPa}$. It is clear that by assimilating TES CO into GEOS-Chem the comparison with MOPITT is greatly improved with a $60 \%$ reduction in the bias. Noncoincident comparisons between TES and MOPITT have shown that MOPITT has a small positive bias with respect to TES (Luo et al., 2006), but this type of comparison can only be conducted with large datasets which must be averaged and interpolated before comparisons can be made.

The zonal mean total column of $\mathrm{CO}$ from MOPITT and GEOS-Chem simulation/assimilation were calculated and the results are shown in Fig. 2. Both MOPITT and model results exhibit similar latitudinal distribution. Figure 2 shows that MOPITT retrieved CO column density in the southern tropics are up to $60 \%$ greater than that 25 from the standard GEOS-Chem simulation. This enhancement of $\mathrm{CO}$ as indicated by MOPITT retrievals is better reproduced in GEOS-Chem results with assimilation of TES CO data - the discrepancy is reduced by a factor of 4 to just $13 \%$. The comparison here points to an underestimate of the biomass burning emissions as used in

Assimilation of TES CO

N. A. D. Richards et al.

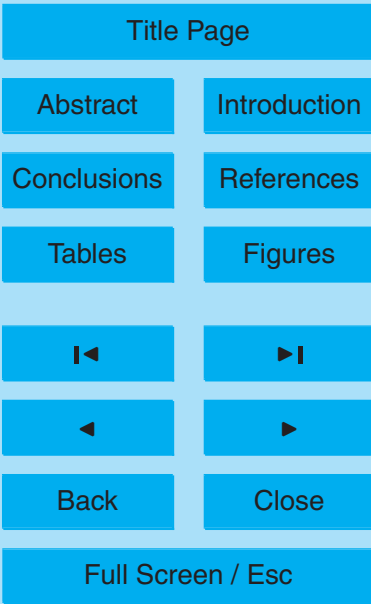

Printer-friendly Version

Interactive Discussion 
the GEOS-Chem simulation presented here in the southern tropics, particularly South America and the Indonesia/Australia region. A previous study of inverse modeling of MOPITT CO columns using GEOS-Chem has shown an underestimation of biomass burning emissions of CO in these regions (Arellano et al., 2004).

\section{$5 \quad 5.2$ Comparison with MOZAIC CO observations}

The MOZAIC program measures $\mathrm{CO}$ in the upper troposphere at the aircraft cruising altitude (between 200-300 hPa) and also profiles during take-off and landing (Nédélec et al., 2003, 2005). Figure 3 shows two CO profiles obtained by MOZAIC aircraft on 15 November 2004. The first (left panel) was taken during a take-off from Toronto 10 airport. Both the model and the observations show similar vertical distributions with higher concentrations in the boundary layer and an enhanced layer of $\mathrm{CO}$ at $400 \mathrm{hPa}$. The assimilation does not change the vertical distribution significantly but increases CO concentrations between 800 and $200 \mathrm{hPa}$ which are now in better agreement with the observations. The second profile (centre panel) was taken during a descent to 15 Vienna. The polluted boundary layer is evident in both the observation and model results. The profile also shows an enhanced layer of CO between 300 and $400 \mathrm{hPa}$ that is not captured by the model without assimilation of TES data. Back trajectories (not shown here) indicate that the enhanced $\mathrm{CO}$ layer originated in the boundary layer over the United States five days earlier, before being lifted to the upper troposphere and transported across the North Atlantic. Although there were no TES observations that were coincident with the aircraft measurements, GEOS-Chem results with the assimilation capture the enhanced $\mathrm{CO}$ layer in the upper troposphere. This demonstrates the usefulness of the assimilation for non-coincident comparisons. The right panel in Fig. 3 shows the mean CO profile differences between MOZAIC and GEOS-Chem with and without assimilation for all MOZAIC profiles taken on 14 and 15 November 2004, the last two days of the assimilation period, by which time the assimilation has ingested one complete global cycle of TES data. The results show little improvement in the lower troposphere where TES is less sensitive, whereas in the middle to upper tropo-

Assimilation of TES co

N. A. D. Richards et al.

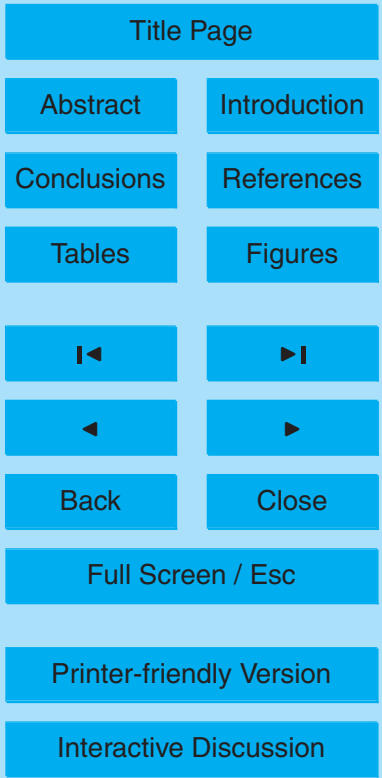


sphere (above $700 \mathrm{mb}$ ) the differences between the assimilated and non-assimilated cases are more substantial with a reduction in the GEOS-Chem - MOZAIC bias of $80 \%$ at $300 \mathrm{mb}$. The assimilation of TES data into GEOS-Chem is able to reduce the average bias with respect to MOZAIC to less than $10 \mathrm{ppbv}$ in the middle and upper 5 troposphere. The comparisons suggest that TES CO profiles are consistent with the in situ observations of MOZAIC, but exhibit a negative bias of up to $10 \mathrm{ppbv}$ in the middle troposphere (between 700 and $400 \mathrm{mb}$ ).

\section{Summary and conclusions}

We presented results of the first assimilation of TES CO profile measurements into 10 the GEOS-Chem global 3-D CTM. The simulation was conducted for 1-15 November 2004. The decreasing observation minus forecast (OMF) with time suggests that the assimilation is performing well. By comparing assimilated with non-assimilated GEOSChem simulations we found differences of up to $50 \mathrm{ppbv}$ in the middle troposphere over the southern tropics. These differences point to a likely underestimation of the 15 biomass burning emissions as prescribed in the model. The assimilation of TES CO significantly improves comparisons with model $\mathrm{CO}$ profiles convoluted with MOPITT averaging kernels, reducing the MOPITT - model bias by up to two thirds in the middle and upper troposphere. Comparisons of assimilated profiles with MOZAIC aircraft measurements of $\mathrm{CO}$ mixing ratio profiles show that TES exhibits a small negative bias

20 of up to $10 \mathrm{ppbv}$ in the middle troposphere (between 700 and $400 \mathrm{mb}$ ). The assimilation is also able to capture a large-scale transport event in the upper troposphere. These results demonstrate the utility of data assimilation for validation of non-coincident satellite measurements, enabling comparisons to be conducted on a profile by profile basis. Future improvements in the comparisons are also expected as the TES optical bench warm up activities in December 2005 improved the TES CO measurement region by more that a factor of 2 compared with the 1-15 November 2004 period used in this research (Rinsland et al., 2006). In addition, planned temperature and cloud retrieval

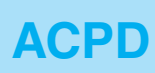

$6,11727-11743,2006$

Assimilation of TES CO

N. A. D. Richards et al.

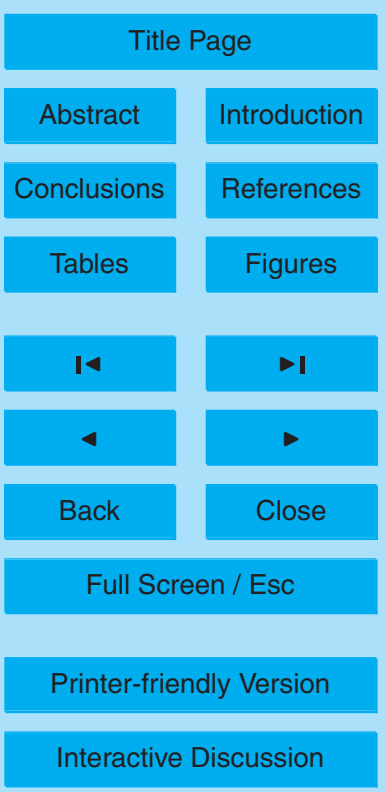


refinements in V003 are expected to further improve the TES CO observations used in the assimilations.

Acknowledgements. This work was performed at Jet Propulsion Laboratory, California Institute of Technology, under contract with NASA. We are thankful to all colleagues and associates for 5 contributing to the EOS TES project. The authors acknowledge for their strong support the European Commission, Airbus, CNRS-France, FZJ-Germany and the airlines (Lufthansa, Air France, Austrian and former Sabena) who carry free of charge the MOZAIC instrumentation since 1994.

\section{References}

Arellano, A. F., Kasibhatla, P. S., Giglio, L., et al.: Top-down estimates of global CO sources using MOPITT measurements, Geophys. Res. Lett., 31, L01104, doi:10.1029/2003GL018609, 2004.

Beer, R., Glavich, T. A., and Rider, D. M.: Tropospheric emission spectrometer for the Earth Observing System's Aura satellite, Appl. Opt., 40(15), 2356-2367, 2001.

15 Bey, I., Jacob, D. J., Yantosca, R. M., et al.: Global modeling of tropospheric chemistry with assimilated meteorology: Model description and evaluation, J. Geophys. Res., 106, $23073-$ $23089,2001 a$.

Bey, I., Jacob, D. J., Logan, J. A., and Yantosca, R. M.: Asian chemical outflow to the Pacific: Origins, pathways and budgets, J. Geophys. Res., 106, 23 097-23 113, $2001 \mathrm{~b}$.

Bowman, K. W., Worden, J., Steck, T., et al.: Capturing time and vertical variability oftropospheric ozone: A study using TES nadir retrievals, J. Geophys. Res., 107(D23), 4723, doi:10.1029/2002JD002150, 2002.

Brasseur, G. P., Hauglustaine, D. A., Walters, S., et al.: MOZART, a global chemical transport model for ozone and related chemical tracers 1. Model description, J. Geophys. Res.-Atmos., 103, 28265-28289, 1998.

Deeter, M. N., Emmons, L. K., Edwards, D. P., Gille, J. C., and Drummond, J. R.: Vertical resolution and information content of $\mathrm{CO}$ profiles retrieved by MOPITT, Geophys. Res. Lett., 31, L15112, doi:10.1029/2004GL020235, 2004.

Drummond, J. R.: Measurements of Pollution in the Troposphere (MOPITT), in The Use of EOS for Studies of Atmospheric Physics, 1269-1284, North-Holland, Amsterdam.

\section{Assimilation of TES} CO

N. A. D. Richards et al.

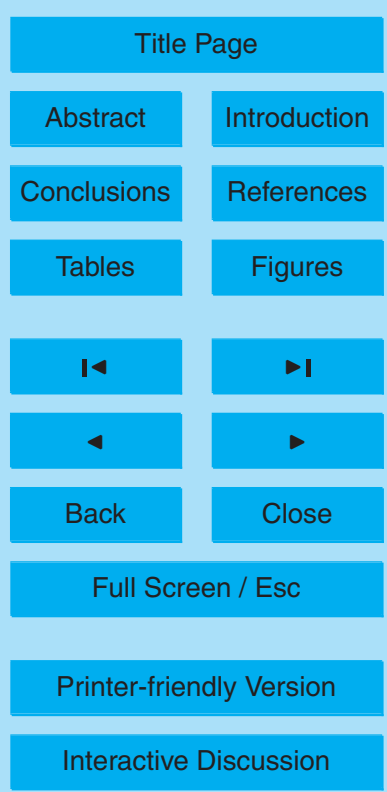


Duncan, B. N., Martin, R. V., Staudt, A. C., et al.: Interannual and seasonal variability of biomass burning emissions constrained by satellite observations, J. Geophys. Res., 108(D2), 4100, doi:10.1029/2002JD002378, 2003.

Emmons, L. K., Martin, R. V., Staudt, A. C., Yevich, R. M., and Logan, J. A.: Validation of Measurements of Pollution in the Troposphere (MOPITT) CO retrievals with aircraft in situ profiles, J. Geophys. Res., 109, D03309, doi:10.1029/2003JD004101, 2004.

Errico, R. M.: Workshop on the assimilation of satellite data, Bull. Am. Meteorol. Soc., 80, 463-471, 1999.

Jones, D. B., Bowman, K. W., Palmer, K. W., et al.: Potential of observations from the Tropospheric Emission Spectrometer to constrain continental sources of carbon monoxide, J. Geophys. Res., 108(D24), 4789, doi:10.1029/2003JD003702, 2003.

Heald, C. L., Jacob, D. J., Fiore, A. M., et al.: Transpacific satellite and aircraft observations of Asian pollution, J. Geophys. Res., 108 (D24), 4804, doi:10.1029/2003JD003507, 2003.

Khattatov, B. V., Lamarque, J.-F., Lyjak, L. V., et al.: Assimilation of satellite observations of 15 long-lived chemical species in global chemistry transport models, J. Geophys. Res., 105, 23, 29 135-29 144, 2000.

Lamarque, J.-F., Khattatov, B., Yudin, V., et al.: Application of a bias estimator for the improved assimilation of Measurements of Pollution in the Troposphere (MOPITT) carbon monoxide retrievals, J. Geophys. Res., 109(D16), D16304, doi:10.1029/2003JD004466, 2004.

Levelt, P. F., Khattatov, B. V., Gille, J. C., et al.: Assimilation of MLS ozone measurements in the global three-dimensional chemistry-transport model ROSE, Geophys. Res. Lett., 25, 4493-4496, 1998.

Liu, H., Jacob, D. J., Bey, I., et al.: Transport pathways for Asian pollution outflow over the Pacific: Interannual and seasonal variations, J. Geophys. Res., 108(D20), 8786, doi:10.1029/2002JD003102, 2003.

Luo, M., Rinsland, C., Rodgers, C., Logan, J., et al.: The influences of a priori data and instrument characteristics on nadir atmospheric species retrievals-Comparison of $\mathrm{CO}$ retrievals from TES and MOPITT, J. Geophys. Res., in press, 2006.

Marenco, A., Thouret, V., Nedelec, P., et al.: Measurement of ozone and water vapor by Airbus 30 in-service aircraft: The MOZAIC airborne program, An overview, J. Geophys. Res., 103, $25631-25642,1998$.

McMillan, W. W., Barnet, C., Strow, M. T., et al.: Daily global maps of carbon monoxide from NASA's Atmospheric Infrared Sounder, Geophys. Res. Lett., 32, L11801,

\section{Assimilation of TES} CO

N. A. D. Richards et al.

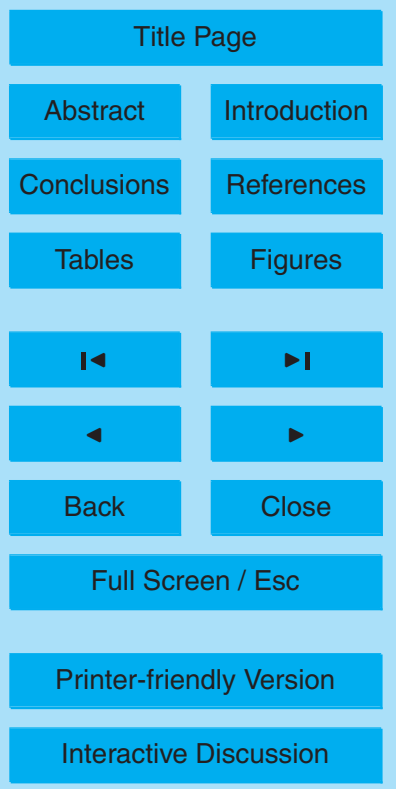


doi:10.1029/2004GL021821, 2005.

Nédélec, P., Thouret, V., Brioude, J., et al.: Extreme CO concentrations in the upper troposphere over North-East Asia in June 2003 from the in-situ MOZAIC aircraft data, Geophys. Res. Lett., 32, L14807, doi:10.1029/2005GL023141, 2005.

5 Nédélec, P., Cammas, J. P., Thouret, V., et al.: An Improved Infra-Red Carbon Monoxide Analyser for Routine Measurements aboard Commercial Airbus Aircraft: Technical Validation and First Scientific Results of the MOZAIC III Program, Atmos. Chem. Phys., 1551-1564, 2003.

Osterman, G. B. (Ed.): TES Validation Report, Version 1.00, 2005, available at: http://eosweb. larc.nasa.gov/PRODOCS/tes/table_tes.html, 2005.

10 Park, M., Randel, W. J., Kinnison, D. E., et al.: Seasonal variations of Methane, Water Vapor, Ozone, and Nitrogen Dioxide near the tropopause: Satellite Observations and Model Simulations, J. Geophys., Res., 109, D03302, doi10.1029/2003JD003706, 2004.

Rinsland, C. P., Luo, M., Logan, J., et al.: Nadir Measurements of Carbon Monoxide (CO) Distributions by the Tropospheric Emission Spectrometer Instrument onboard the Aura Spacecraft: Overview of Analysis Approach and Examples of Initial Results, Geophys. Res. Lett., in press, 2006.

Rodgers, C. D.: Inverse Methods for Atmospheric Sounding: Theory and Practice. Singapore, World Scientific, 2000.

Van der Werf, G. R., Randerson, J. T., Giglio, L., et al.:, Interannual variability in global biomass burning emission from 1997-2004, Atmos. Chem. Phys., 6, 3423-3441, 2006.

Worden, J., Kulawik, S. S., Shephard, M. W., et al.: Predicted errors of tropospheric emission spectrometer nadir retrievals from spectral window selection, J. Geophys. Res., 109(D9), D09308, doi:10.1029/2004JD004522, 2004.

Yudin, V. A., Pétron, G., Lamarque, J.-F., et al.: Assimilation of the 2000-2001 CO MOPITT retrievals with optimized surface emissions, Geophys. Res. Lett., 31, L20105, doi:10.1029/2004GL021037, 2004.

Yu, H., Dickinson, R. E., Chin, M., et al.: Annual cycle of global distributions of aerosol optical depth from integration of MODIS retrievals and GOCART model simulations, J. Geophys. Res., 108(D3), 4128, doi:10.1029/2002JD002717, 2003.

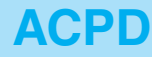

$6,11727-11743,2006$

Assimilation of TES CO

N. A. D. Richards et al.

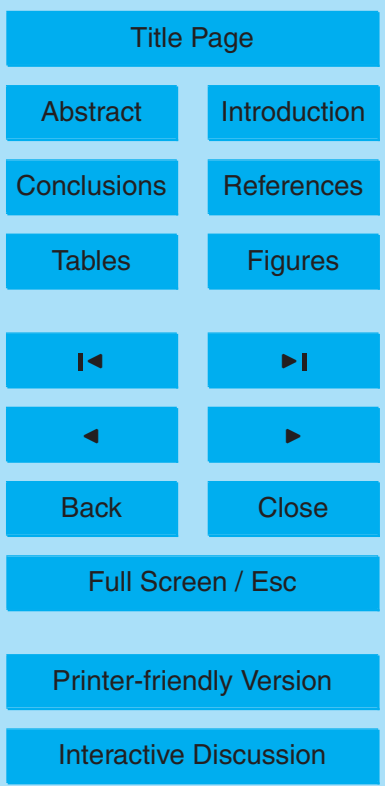




\section{ACPD}

$6,11727-11743,2006$

\section{Assimilation of TES CO}

N. A. D. Richards et al.

Table 1. Global mean bias of GEOS-Chem - MOPITT before and after assimilation of TES CO observations.

\begin{tabular}{ccc}
\hline Pressure $(\mathrm{mb})$ & Bias (No Assim) & Bias (Assim) \\
\hline Surface & $-16 \%$ & $-16 \%$ \\
850 & $-32 \%$ & $-16 \%$ \\
150 & $-16 \%$ & $-5 \%$ \\
250 & $-18 \%$ & $-6 \%$ \\
350 & $-19 \%$ & $-7 \%$ \\
500 & $-20 \%$ & $-8 \%$ \\
700 & $-26 \%$ & $-13 \%$ \\
\hline
\end{tabular}

\section{Title Page}

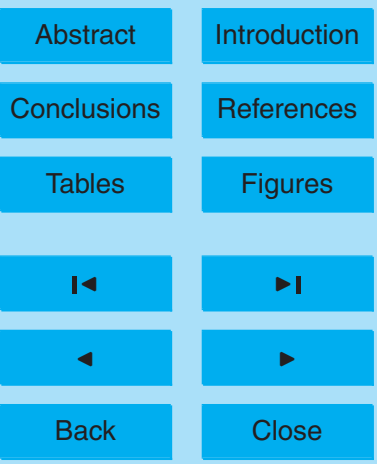

Full Screen / Esc

Printer-friendly Version

Interactive Discussion 


\section{ACPD}

Non-Assimiloted $\mathrm{CO}$ ot $5.5 \mathrm{~km}$
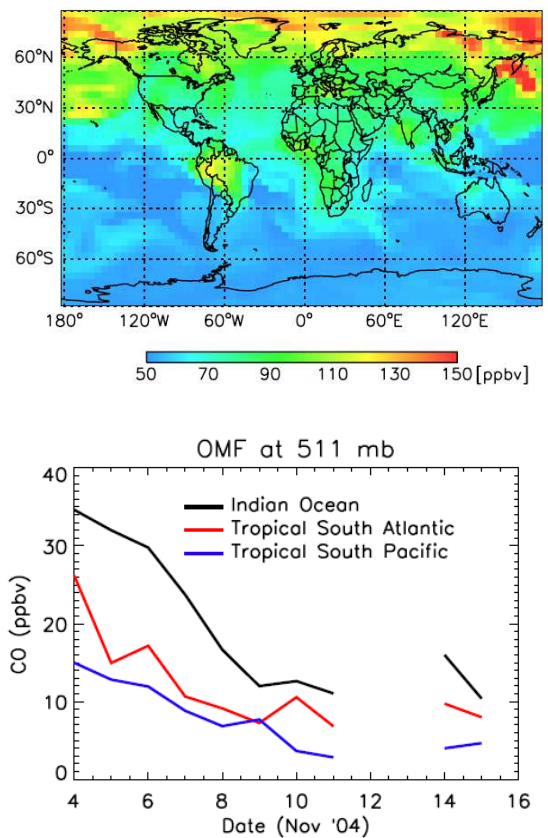

Assimilated $\mathrm{CO}$ ot $5.5 \mathrm{~km}$
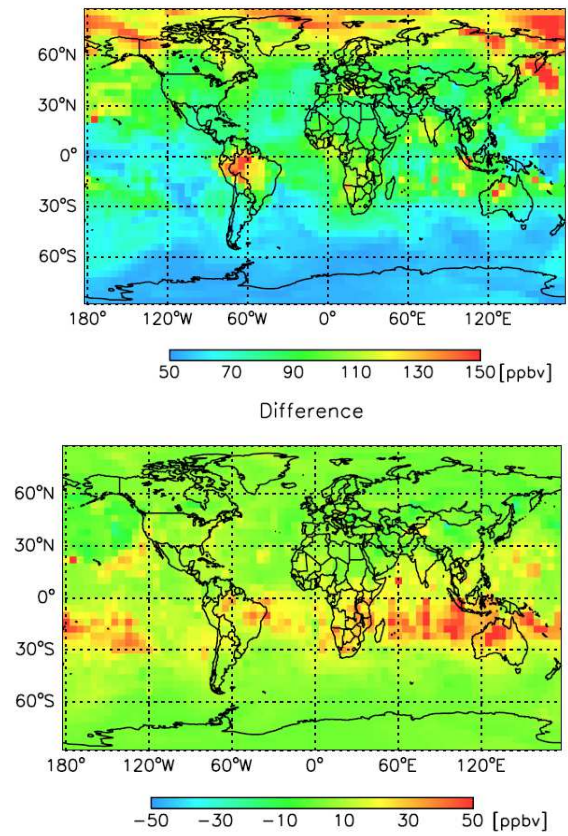

6, 11727-11743, 2006

\section{Assimilation of TES} CO

N. A. D. Richards et al.

Title Page

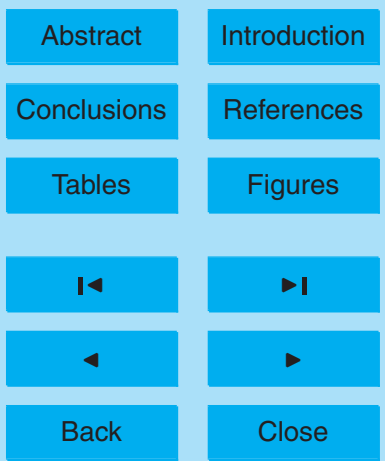

Full Screen / Esc

Printer-friendly Version

Interactive Discussion

Fig. 1. GEOS-Chem non-assimilated (top left) and assimilated (top right) $\mathrm{CO}$ at $5.5 \mathrm{~km}$ on 15 November 2004, the last day of the assimilation run. Also shown are the difference between the assimilated and non-assimilated fields (bottom right) and observation minus forecast (OMF) time series (bottom left) for three southern tropical ocean regions. 


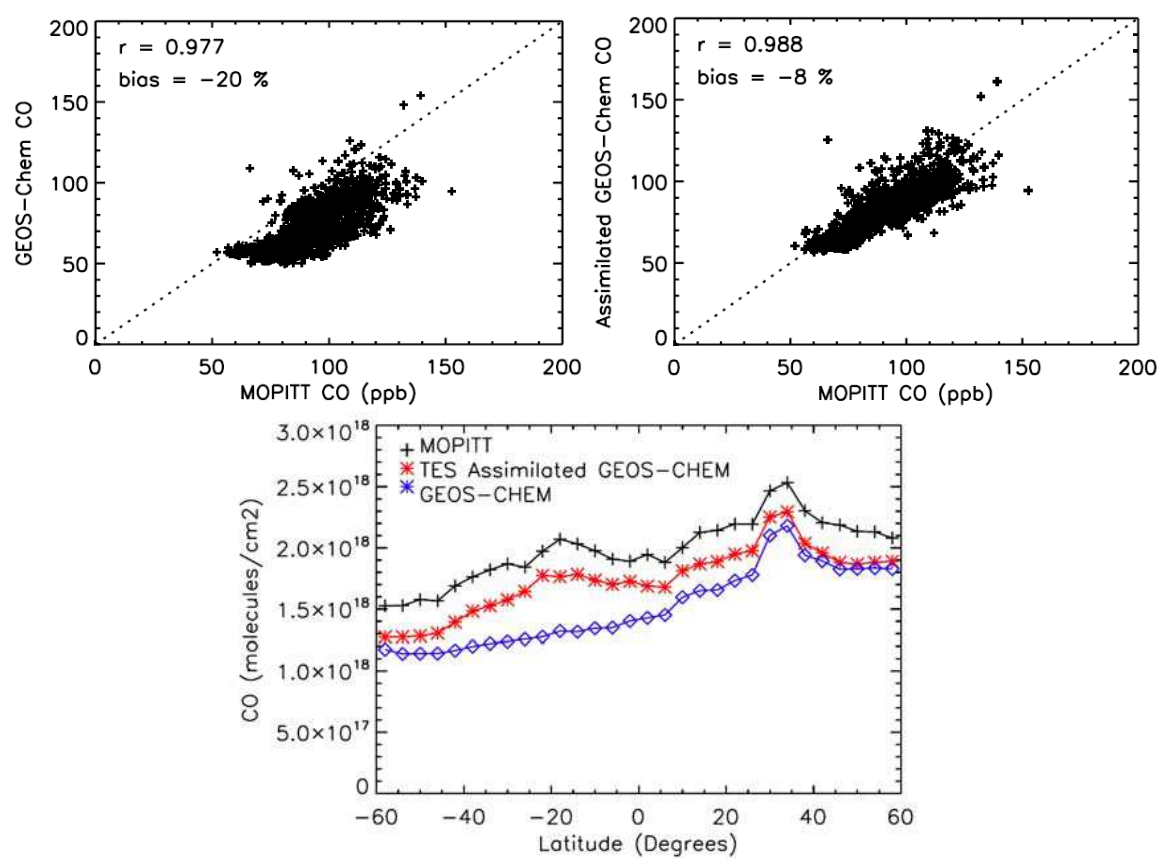

Fig. 2. Comparison of MOPITT with GEOS-Chem non-assimilated (top left) and assimilated (top right) $\mathrm{CO}$ concentrations at $500 \mathrm{mb}$ and zonal mean columns (bottom) for 15 November 2004.
ACPD

$6,11727-11743,2006$

\section{Assimilation of TES CO}

N. A. D. Richards et al.

\section{Title Page}

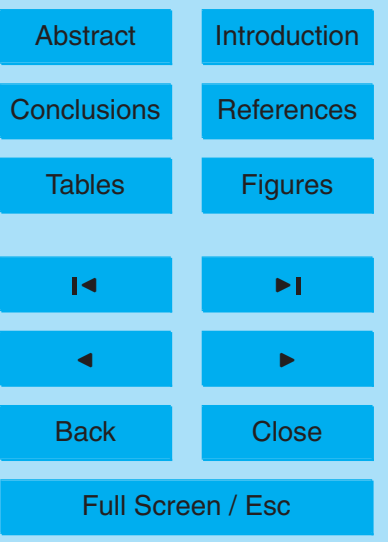

Printer-friendly Version

Interactive Discussion 


\section{ACPD}

$6,11727-11743,2006$
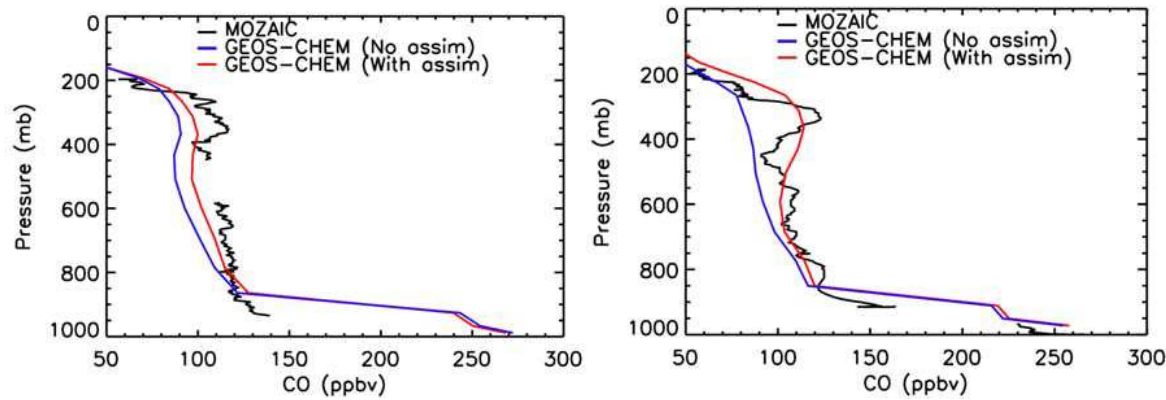

\section{Assimilation of TES CO}

N. A. D. Richards et al.

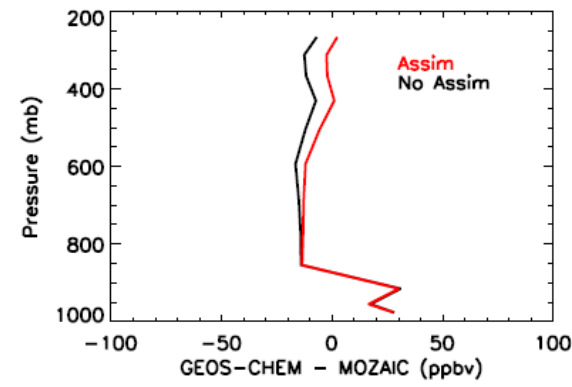

\section{Title Page}

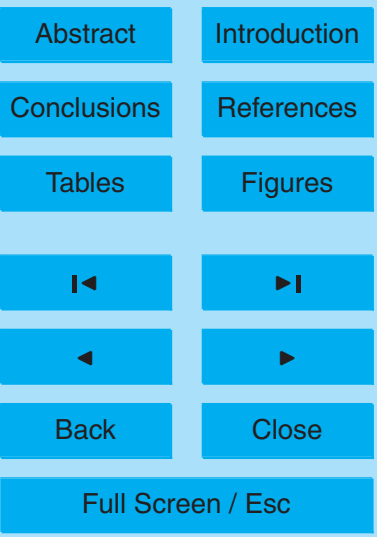

Fig. 3. Comparison of GEOS-Chem non-assimilated and assimilated CO profiles with MOZAIC observed profiles taken over Toronto (top left), Vienna (top right) and the mean differences between GEOS-Chem and all MOZAIC profiles taken on 14 and 15 November 2004 (bottom). 